\title{
A New Approach to the Synthesis of Cyanamide: 2-Cyanoimino-4-aryl-6-(naphthalen-2-yl)-3,4-dihydro- $1 H$-pyrimidines and their Antimicrobial Screening
}

\author{
N.PRAKASH, M.ELAMARAN and N. INGARSAL ${ }^{*}$ \\ P G and Research Department of Chemistry, \\ Rajah Serfoji Govt. College, Thanjavur-05, Tamilnadu, India \\ ningars@rediffmail.com
}

Received 8 July 2015 / Accepted 24 July 2015

\begin{abstract}
A series of cyanoiminopyrimidines were synthesized by the reaction of 1-(2-naphthyl)-3arylprop-2-en-1-ones with cyanoguanidine in the presence of sodium hydroxide in ethanol. The mechanism involves the 1,4 or 1,2-addition of cyanoguanidine to $\alpha, \beta$-unsaturated ketone, heterocyclisation and subsequent tautomeric change of formed adduct with loss of water. All the newly synthesized compounds were characterized by IR and NMR spectral studies. The in vitro antimicrobial screening of synthesized compounds showed the significant antifungal activities compared to the standard fluconazole.
\end{abstract}

Keywords: Synthesis, Acetylnaphthalene, Chalcones, Cyanoguanidine, Cyanoiminopyrimidines

\section{Introduction}

In recent years the substituted aminopyrimidine derivatives impart a potent place in pharmaceutical field due to their high medicinal values. They act as very good antimicrobial $^{1}$, anticancer ${ }^{2}$, antipyretic ${ }^{3}$ etc. The cyanoguanidine and their derivatives such as pyridylcyanoguanidine with hydrophobic aromatic side chains showed potent antiproliferative activity in the human breast and lung cancer cell lines ${ }^{4}$. Also the $N$-cyanoguanidinyl moiety is found in other biologically active molecules such as $N$-cyanoiminopyrimidine (antimycotic agent) ${ }^{5}$, pinacidil, a $\mathrm{K}_{\text {ATP }}$ channel activator ${ }^{6}$ etc. In cyanoimino pyrimidines, the presence of more stable imino form $(-\mathrm{C}=\mathrm{N})$ compared to amino form $(-\mathrm{C}-\mathrm{NH})$, the basicity of the nitrogen atom in the nitrile group $(\mathrm{C}=\mathrm{N}-\mathrm{C} \equiv \mathrm{N})$ is appreciably increases ${ }^{7}$ and thus can act as very good synthons ${ }^{8}$ of pharmacologically active products and are also having hypoglycaemic ${ }^{9}$ activity.

There are several reports involves the synthesis of 2-cyanoiminopyrimidines by (i) Multicomponent reaction of 1,3-dicarbonyl compounds, cyanamides and aromatic aldehydes ${ }^{10}$ (ii) condensation of cyanoguanidine with acrylic acid derivatives ${ }^{11}$. The multicomponent reaction of aromatic aldehydes, cyanoguanidine and acetyl compounds give the corresponding pyrimidin-2-ylcyanamide ${ }^{12}$ (Figure 1) instead of dihydrocyanoiminopyrimidines. 


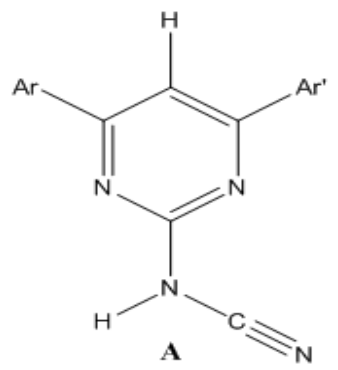

Figure 1. Structure of structure of pyrimidin-2-ylcyanamide

Here we report the synthesis of 4,6-diaryl-3,4-dihydro-2-cyanoiminopyrimidines by the reaction of $\alpha, \beta$-unsaturated ketones derived from the simple Claisen-Schmidt condensation of easily available aromatic aldehydes and acetylnaphthalene in a viable method.

\section{Experimental}

All chemicals were of analytical grade and purchased from E-Merck. The solvents were distilled before use. Melting points of the prepared compounds were determined in open capillary tubes and are uncorrected. The purity of the compounds were checked by silica gel coated aluminium plates. The FT-IR spectra were recorded on NICOLET AVATAR-360 FT-IR instrument by using $\mathrm{KBr}$ pellets. The ${ }^{1} \mathrm{H}$ and ${ }^{13} \mathrm{C}$ NMR spectra were recorded on Brucker AMX-400 spectrometer operating at $400 \mathrm{MHz}$ using $\mathrm{CDCl}_{3}$ as solvent and TMS as the internal standard. The stability of these tautomers were analysed by QuantumMechanical calculation using [DFT-B3LYP/6-31g (d)] method.

\section{Antimicrobial activity}

The In vitro antimicrobial activity was carried out by using Mueller-Hinton broth method. Antibacterial activities were screened against two gram positive and two gram negative bacterias. Antifungal activities were screened against Aspergillus flavus and Aspergillus niger. The microorganisms were collected from microbial type culture collection and gene bank (MTCC), Chandigarh, India. Both antibacterial and antifungal activities were studied by measuring the zone of inhibition on agar plates at concentration $10 \mu \mathrm{g} / \mathrm{mL}$ and gentamicin used as the standard for antibacterial and fluconazole used as the standard for antifungal activities respectively.

\section{Preparation of 1-(2-naphthyl)ethanone (2)}

A mixture of $41.9 \mathrm{~g}(0.53 \mathrm{M})$ of acetyl chloride and $100 \mathrm{~mL}$ of carbontetrachloride was taken in a one-liter three necked flask. The flask was equipped with condenser carrying a guard tube and a dropping funnel. About $70 \mathrm{~g}(0.52 \mathrm{M})$ of powdered dry $\mathrm{AlCl}_{3}$ was added slowly to the vigorously stirred mixture. The mixture was cooled to $20{ }^{\circ} \mathrm{C}$ and a solution of naphthalene $(32 \mathrm{~g}, 0.25 \mathrm{M})$ in $100 \mathrm{~mL}$ of $\mathrm{CCl}_{4}$ was added for 90 minutes from the dropping funnel. After the completion of the addition, the mixture was warmed to $30{ }^{\circ} \mathrm{C}$ for 30 minutes. The resulting mixture was decomposed with ice and concentrated hydrochloric acid. The product separated and crystallized from ethanol. Yield: $70 \%$, Melting Point: $54-56{ }^{\circ} \mathrm{C}$.

Preparation of 1-(2-naphthyl)-3-arylprop-2-en-1-ones (3a-g)

A mixture of substituted benzaldehyde $(0.01 \mathrm{M})$ and 1-(2-naphthyl)ethanone $(0.01 \mathrm{M})$ in ethanol $(50 \mathrm{~mL})$ was taken in a $250 \mathrm{~mL}$ round-bottomed flask. The reaction mixture was heated over a water bath while a solution of sodium hydroxide ( $1 \mathrm{~g}$ in $5 \mathrm{~mL}$ of water) was added 
during 15 minutes and heating was continued another 15 minutes. The solution was cooled, the product thus obtained was filtered and recrystallized from ethanol.

General procedure for the preparation of 2-cyanoimino-4-aryl-6-(naphthalen-2-yl)3,4-dihydro-1H-pyrimidine (4a-g)

Appropriate chalcones $(3 \mathbf{a}-\mathbf{g})(0.01 \mathrm{M})$ and cyanoguanidine $(0.01 \mathrm{M})$ in ethanol $(75 \mathrm{~mL})$ were refluxed in the presence of sodium hydroxide $(0.05 \mathrm{M}$ in $10 \mathrm{~mL}$ of water). The reaction was monitored by TLC and after completion of the reaction (nearly after 2 hours), the reaction mass was concentrated to one third volume under vacuum. The concentrated mass was poured in to ice cold water and filtered. The separated product was purified by column chromatography using silica gel as a stationary phase and benzene: ethylacetate (8:2) as mobile phase.

\section{The physical and spectral data of the synthesized compounds}

\section{2-Cyanoimino-4-phenyl-6-(naphthalen-2-yl)-3,4-dihydro-1H-pyrimidine (4a)}

M.F: $\mathrm{C}_{21} \mathrm{H}_{16} \mathrm{~N}_{4}$, Yield: $93 \%$, M.P: $91{ }^{\circ} \mathrm{C}$; IR $\left(\mathrm{KBr}, \mathrm{cm}^{-1}\right)$ : $3180.40(\mathrm{NH}), 2179.41(\mathrm{C} \equiv \mathrm{N})$, $1629.74(\mathrm{C}=\mathrm{N}), 1527.52(\mathrm{C}=\mathrm{C}) ;{ }^{1} \mathrm{H}$ NMR $(\delta, \mathrm{ppm}): 5.36\left(\mathrm{~d}, 2 \mathrm{H}, \mathrm{C}_{4} \mathrm{H} \& \mathrm{C}_{5} \mathrm{H}\right), 6.34(\mathrm{~s}, 1 \mathrm{H}$, $\mathrm{NH}), 7.38-7.88[\mathrm{~m}, 12 \mathrm{H}(\mathrm{Ar}-\mathrm{H})+1 \mathrm{H}(\mathrm{NH})] ;{ }^{13} \mathrm{C}$ NMR $(\delta, \mathrm{ppm}): 155.90(\mathrm{C}-2), 56.42(\mathrm{C}-4)$, $101.26(\mathrm{C}-5), 141.63(\mathrm{C}-6), 117.0(\mathrm{C} \equiv \mathrm{N})$ and 122.61-133.70 (Ar-C).

2-Cyanoimino-4-(2-chlorophenyl)-6-(naphthalen-2-yl)-3,4-dihydro-1Hpyrimidine (4b)

M.F: $\mathrm{C}_{21} \mathrm{H}_{15} \mathrm{~N}_{4} \mathrm{Cl}$, Yield: $96 \%$, M.P: $89^{\circ} \mathrm{C}$; IR $\left(\mathrm{KBr}, \mathrm{cm}^{-1}\right): 3425.34(\mathrm{NH}), 2177.48(\mathrm{C} \equiv \mathrm{N})$, $1625.88(\mathrm{C}=\mathrm{N}), 1512.09(\mathrm{C}=\mathrm{C}), 752.19(\mathrm{C}-\mathrm{Cl}) ;{ }^{1} \mathrm{H}$ NMR $(\delta, \mathrm{ppm}): 5.41\left(\mathrm{dd}, 1 \mathrm{H}, \mathrm{J}_{1,2}=2.0\right.$, $\left.\mathrm{J}_{1,3}=4.0, \mathrm{C}_{4} \mathrm{H}\right), 5.84\left(\mathrm{dd}, 1 \mathrm{H}, \mathrm{J}_{1,2}=2.0, \mathrm{~J}_{1,3}=4.0, \mathrm{C}_{5} \mathrm{H}\right), 6.38(\mathrm{~s}, 1 \mathrm{H}, \mathrm{NH}), 8.44$ (merged signal, NH) 7.43-7.88 [m, 11H (Ar-H) + 1H (NH)]; ${ }^{13} \mathrm{C}$ NMR $(\delta, \mathrm{ppm}): 156.29(\mathrm{C}-2), 52.85(\mathrm{C}-4)$, $99.24(\mathrm{C}-5), 138.40(\mathrm{C}-6), 116.61(\mathrm{C} \equiv \mathrm{N}), 122.60-134.46(\mathrm{Ar}-\mathrm{C})$ and $135.02(\mathrm{C}-\mathrm{Cl})$.

\section{2-Cyanoimino-4-(4-methoxyphenyl)-6-(naphthalen-2-yl)-3,4-dihydro-1H-} pyrimidine (4c)

M.F: $\mathrm{C}_{22} \mathrm{H}_{18} \mathrm{~N}_{4} \mathrm{O}$, Yield: $91 \%$, M.P: $92{ }^{\circ} \mathrm{C}$; IR $\left(\mathrm{KBr}, \mathrm{cm}^{-1}\right)$ : $3180.40(\mathrm{NH}), 2179.41(\mathrm{C} \equiv \mathrm{N})$, $1629.74(\mathrm{C}=\mathrm{N}), 1510.16(\mathrm{C}=\mathrm{C}) ;{ }^{1} \mathrm{H}$ NMR $(\delta, \mathrm{ppm}): 5.32\left(\mathrm{~d}, 2 \mathrm{H}, \mathrm{C}_{4} \mathrm{H} \& \mathrm{C}_{5} \mathrm{H}\right), 6.52(\mathrm{~s}, 1 \mathrm{H}$, $\mathrm{NH}), 7.838$ (merged signal, NH), 7.30-7.89 [m, 11H (Ar-H) + 1H (NH)], $3.81[\mathrm{~s}, 3 \mathrm{H}$, $\left.\left(\mathrm{OCH}_{3}\right)\right] ;{ }^{13} \mathrm{C}$ NMR $(\delta, \mathrm{ppm}): 155.81(\mathrm{C}-2), 55.44(\mathrm{C}-4), 101.56(\mathrm{C}-5), 133.93(\mathrm{C}-6), 117.06$ $(\mathrm{C} \equiv \mathrm{N})$ and 122.67-133.93 (Ar-C), $160.04\left(\mathrm{C}-\mathrm{OCH}_{3}\right), 55.79\left(\mathrm{OCH}_{3}\right)$.

\section{2-Cyanoimino-4-(3,4-dimethoxyphenyl)-6-(naphthalen-2-yl)-3,4-dihydro-1H- pyrimidine (4d)}

M.F: $\mathrm{C}_{23} \mathrm{H}_{20} \mathrm{~N}_{4} \mathrm{O}_{2}$, Yield: $90 \%$, M.P: $94{ }^{\circ} \mathrm{C}$; IR $\left(\mathrm{KBr}, \mathrm{cm}^{-1}\right)$ : $3245.97(\mathrm{NH}), 2171.70(\mathrm{C} \equiv \mathrm{N})$, $1627.81(\mathrm{C}=\mathrm{N}), 1515.94(\mathrm{C}=\mathrm{C}) ;{ }^{1} \mathrm{H}$ NMR $(\delta, \mathrm{ppm}): 5.34\left(\mathrm{~d}, 2 \mathrm{H}, \mathrm{C}_{4} \mathrm{H} \& \mathrm{C}_{5} \mathrm{H}\right), 6.24(\mathrm{~s}, 1 \mathrm{H}$, $\mathrm{NH}), 7.841$ (s, NH, merged signal), 7.50-7.89 [m, 10H (Ar-H) + 1H (NH)], $3.90[\mathrm{~s}, 6 \mathrm{H}$, $\left.\left(\mathrm{OCH}_{3}\right)\right] ;{ }^{13} \mathrm{C}$ NMR $(\delta, \mathrm{ppm}): 149.66(\mathrm{C}-2), 56.08(\mathrm{C}-4), 101.38(\mathrm{C}-5), 137.0(\mathrm{C}-6), 119.51$ $(\mathrm{C} \equiv \mathrm{N})$ and 122.56-133.03 ( $\mathrm{Ar}-\mathrm{C}), 155.77\left(\mathrm{C}-\mathrm{OCH}_{3}\right), 56.27\left(\mathrm{OCH}_{3}\right)$.

2-Cyanoimino-4-(4-chlorophenyl)-6-(naphthalen-2-yl)-3,4-dihydro-1H-pyrimidine (4e) M.F: $\mathrm{C}_{21} \mathrm{H}_{15} \mathrm{~N}_{4} \mathrm{Cl}$, Yield: $95 \%$, M.P: $90{ }^{\circ} \mathrm{C}$; IR $\left(\mathrm{KBr}, \mathrm{cm}^{-1}\right): 2177.48(\mathrm{C} \equiv \mathrm{N}), 1625.88(\mathrm{C}=\mathrm{N})$, $1517.87(\mathrm{C}=\mathrm{C}), 752.19(\mathrm{C}-\mathrm{Cl}) ;{ }^{1} \mathrm{H} \operatorname{NMR}(\delta, \mathrm{ppm}): 5.43\left(\mathrm{dd}, 1 \mathrm{H}, \mathrm{J}_{1,2}=2.0 \mathrm{~Hz}, \mathrm{~J}_{1,3}=4.0 \mathrm{~Hz}\right.$, $\left.\mathrm{C}_{4} \mathrm{H}\right), 5.86\left(\mathrm{dd}, 1 \mathrm{H}, \mathrm{J}_{1,2}=2.0, \mathrm{~J}_{1,3}=4.0, \mathrm{C}_{5} \mathrm{H}\right), 6.22(\mathrm{~s}, 1 \mathrm{H}, \mathrm{NH}), 7.844$ (merged signal, NH), 
7.32-7.89 [m, 11H (Ar-H) + 1H (NH)]; ${ }^{13} \mathrm{C}$ NMR ( $\delta$, ppm): $156.20(\mathrm{C}-2), 52.85(\mathrm{C}-4), 99.18$ (C-5), $138.34(\mathrm{C}-6), 116.0(\mathrm{C} \equiv \mathrm{N}), 122.55-133.00(\mathrm{Ar}-\mathrm{C})$ and $134.45(\mathrm{C}-\mathrm{Cl})$.

2-Cyanoimino-4-(4-bromophenyl)-6-(naphthalen-2-yl)-3,4-dihydro-1H-pyrimidine (4f) M.F: $\mathrm{C}_{21} \mathrm{H}_{15} \mathrm{~N}_{4} \mathrm{Br}$, Yield: 94\%, M.P: $87^{\circ} \mathrm{C}$; IR $\left(\mathrm{KBr}, \mathrm{cm}^{-1}\right)$ : $3398.34(\mathrm{NH}), 2175.55(\mathrm{C} \equiv \mathrm{N})$, $1623.95(\mathrm{C}=\mathrm{N}), 1510.16(\mathrm{C}=\mathrm{C}), 756.04(\mathrm{C}-\mathrm{Br}) ;{ }^{1} \mathrm{H}$ NMR $(\delta, \mathrm{ppm}): 5.42\left(\mathrm{~d}, 1 \mathrm{H}, \mathrm{C}_{4} \mathrm{H}\right), 5.79$ $\left(\mathrm{d}, 1 \mathrm{H}, \mathrm{C}_{5} \mathrm{H}\right), 6.55(\mathrm{~s}, 1 \mathrm{H}, \mathrm{NH}), 7.854$ (merged signal, $\left.\mathrm{NH}\right), 7.38-7.98[\mathrm{~m}, 11 \mathrm{H}(\mathrm{Ar}-\mathrm{H})+1 \mathrm{H}$ $(\mathrm{NH})$ ]; ${ }^{13} \mathrm{C}$ NMR ( $\left.\delta, \mathrm{ppm}\right): 156.35$ (C-2), 55.14 (C-4), 99.84 (C-5), 139.93 (C-6), 116.58 $(\mathrm{C} \equiv \mathrm{N}), 121.36-134.17(\mathrm{Ar}-\mathrm{C})$ and $134.66(\mathrm{C}-\mathrm{Br})$.

2-Cyanoimino-4-(4-methylphenyl)-6-(naphthalen-2-yl)-3,4-dihydro-1H-pyrimidine (4g) M.F: $\mathrm{C}_{22} \mathrm{H}_{18} \mathrm{~N}_{4}$, Yield: $92 \%$, M.P: $93{ }^{\circ} \mathrm{C}$; IR $\left(\mathrm{KBr}, \mathrm{cm}^{-1}\right)$ : $3230.54(\mathrm{NH}), 2181.34(\mathrm{C} \equiv \mathrm{N}), 1627.81$ $(\mathrm{C}=\mathrm{N}), 1525.59(\mathrm{C}=\mathrm{C}) ;{ }^{1} \mathrm{H}$ NMR $(\delta, \mathrm{ppm}): 5.33\left(\mathrm{~d}, 2 \mathrm{H}, \mathrm{C}_{4} \mathrm{H} \& \mathrm{C}_{5} \mathrm{H}\right), 6.27(\mathrm{~s}, 1 \mathrm{H}, \mathrm{NH}), 7.26-$ $7.87[\mathrm{~m}, 11 \mathrm{H}(\mathrm{Ar}-\mathrm{H})+1 \mathrm{H}(\mathrm{NH})], 2.37,\left(\mathrm{~s}, 3 \mathrm{H}, \mathrm{CH}_{3}\right) ;{ }^{13} \mathrm{C} \mathrm{NMR}(\delta, \mathrm{ppm}): 155.85(\mathrm{C}-2), 56.16$ (C-4), $101.46(\mathrm{C}-5), 138.97(\mathrm{C}-6), 116.87(\mathrm{C} \equiv \mathrm{N})$ and $122.60-138.74(\mathrm{Ar}-\mathrm{C})$ and $21.23\left(\mathrm{CH}_{3}\right)$.

\section{Results and Discussion}

2-Cyanoimino-4-aryl-6-(naphthalen-2-yl)-3,4-dihydro- $1 H$-pyrimidines have been synthesized in the following mannar. The Claisen-Schmidt condensation of 2-acetylnaphthalene with aromatic aldehydes in the presence of base gives the corresponding 1-(2-naphthyl)-3-arylprop-2-en-1-ones (3a-g). Then (3a-g) on further treatment with cyanoguanidine in the presence of sodium hydroxide in ethanol afford the corresponding 2-cyanoimino-4-aryl-6(naphthalen-2-yl)-3,4-dihydro-1H-pyrimidines (4a-g) (Scheme 1).

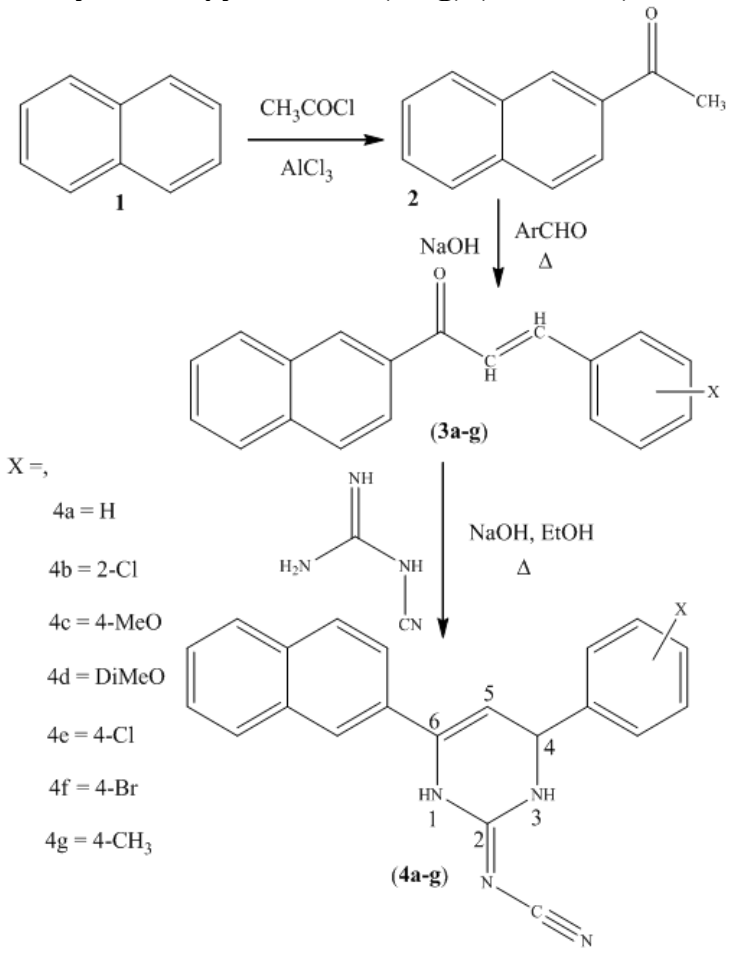

Scheme 1. Formation of cyanoiminopyrimidines 
The reaction of chalcone with cyanoguanidine in presence of base yields dihydrocyanoiminopyrimidine. The formation of this product might proceed either by route (i) 1,4-addition or (ii) 1,2-addition of cyanoguanidine to the chalcone followed by the cyclisation of the intermediates (Scheme 2) like the mechanism proposed for 2-aminopyrimidines ${ }^{13}$.

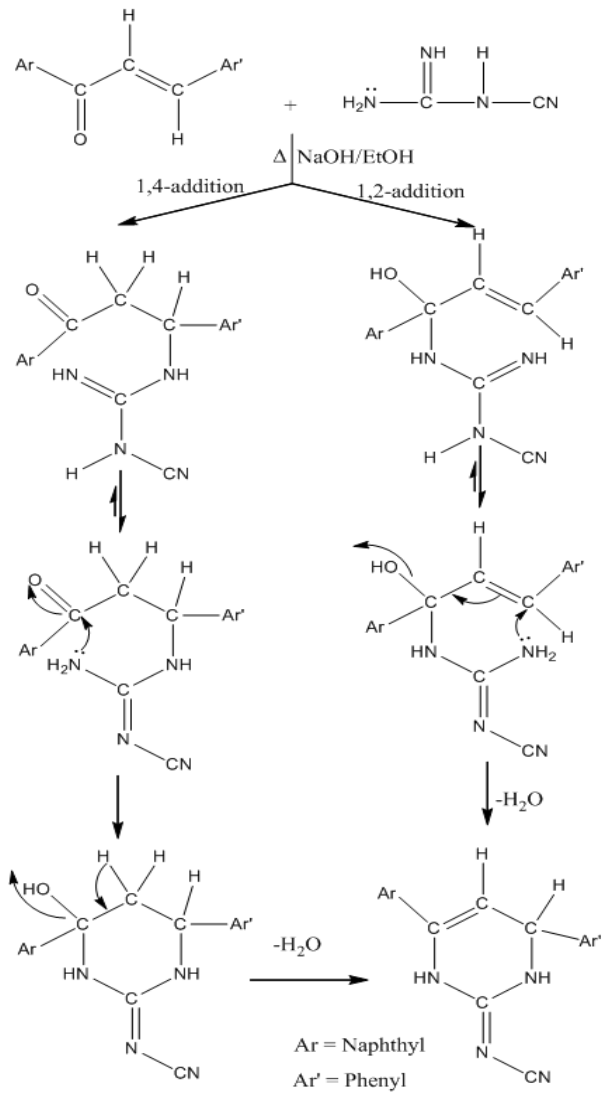

Scheme 2. Machanism for the formation of dithydrocynaiminopyrimidine

The reaction of $\alpha, \beta$-unsaturated ketones with substituted guanidines in basic medium is expected to form aminosubstitutedpyrimidine derivatives. This experiment, insteadof aminosubstituted pyrimidines, the dihydro-2-cyanoiminopyrimidines were obtained. To determine the structure of these synthesized compounds, the NMR, IR and computational experiments were performed.

The ${ }^{1} \mathrm{H}$ NMR spectra of all compounds showed two $\mathrm{D}_{2} \mathrm{O}$ exchangeable signals, one signal at 6.2 to $6.5 \mathrm{ppm}$ as a singlet for one proton and another merged signal is appears in the aromatic region are corresponding to two $-\mathrm{NH}$ protons. The chemical shift values 5.3 to $5.8 \mathrm{ppm}$, there are two types of signals were observed in the ${ }^{1} \mathrm{H}$ NMR spectra of these compounds. The phenyl ring at $4^{\text {th }}$ position of dihydropyrimidine moiety with 4-methoxy or 3,4-dimethoxy or 4-methyl as the substituent and without substitution shows a doublet at 5.3-5.4 ppm for two protons is corresponds to C-4 and C-5 protons but the substituents as 4chloro or 2-chloro or 4-bromo, the protons at C-4 and $\mathrm{C}-5$ position resonates separately at 5.4 and 5.8 ppm respectively. 
The compounds with chloro substitution (4b, $\mathbf{4 e}$ ), observed long range coupling for C-4 and C-5 protons (dd, 5.4 and $5.8 \mathrm{ppm} ; \mathrm{J}_{1,2}=2.0, \mathrm{~J}_{1,3}=4.0 \mathrm{~Hz}$ ). This long range coupling might be the coupling of $\mathrm{C}-4$ and $\mathrm{C}-5$ protons with amino proton and is confirmed by the disappearance of doublet of doublet and appearance of doublet during the addition of $\mathrm{D}_{2} \mathrm{O}$ in the ${ }^{1} \mathrm{H}$ NMR experiment.

The ${ }^{13} \mathrm{C}$ NMR spectrum displayed signals at $155-157,116-117$ and $52-56 \mathrm{ppm}$ due to the imino, cyano and methine carbons and the carbon at C-5 resonates at $99-101 \mathrm{ppm}$. The IR spectra of all the synthesized compounds also support the structural determination by giving the respective vibrational bands at 1625-1630 $(\mathrm{C}=\mathrm{N}), 2171-2181(\mathrm{C} \equiv \mathrm{N}), 3180-3425$ $(-\mathrm{NH})$ and $1510-1527 \mathrm{~cm}^{-1}(\mathrm{C}=\mathrm{C})$ respectively.

The spectroscopic data lead to the unambiguous identification of 4,6-diaryl-2cyanoiminopyrimidine and it may exist in the tautomeric forms $\mathbf{B}$ or $\mathbf{C}$ or $\mathbf{D}$ ( Figure 2 ). The stability of these tautomers are analyzed by Quantum-Mechanical calculation using [DFTB3LYP/6-31g (d)] method, to find the stationary points on the potential energy surfaces confirmed by the frequencies analysis. The relative energies of the tautomers are shown in Figure 3. Thermodynamic parameters such as absolute energy ( $E$ in a.u), relative energy $(\Delta E$ in $\mathrm{kcal} / \mathrm{mol}$ ) and dipole moment (Debey) of these tautomers are listed in Table 1. From the table, the tautomer $\mathbf{D}$ is more stable when compared with others as well as tautomer $\mathbf{B}$ is least stable. This result indicates that the N-H protons are present in ring nitrogens and the $3^{\circ}$ amine favored by electron withdrawing nature of the cyano group.

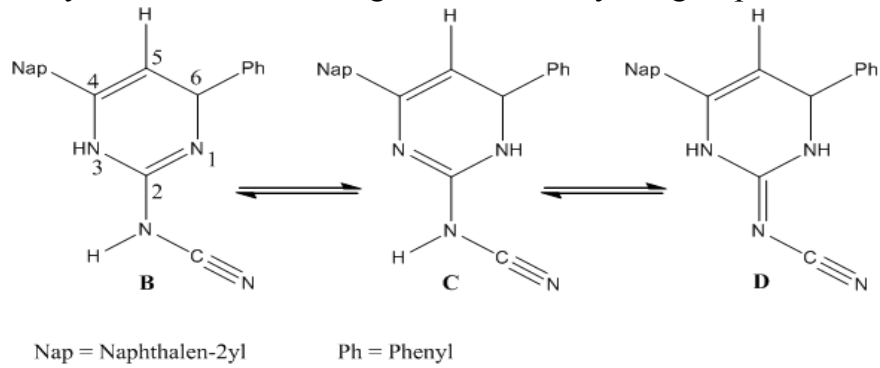

Figure 2. Possible tautomeric forms

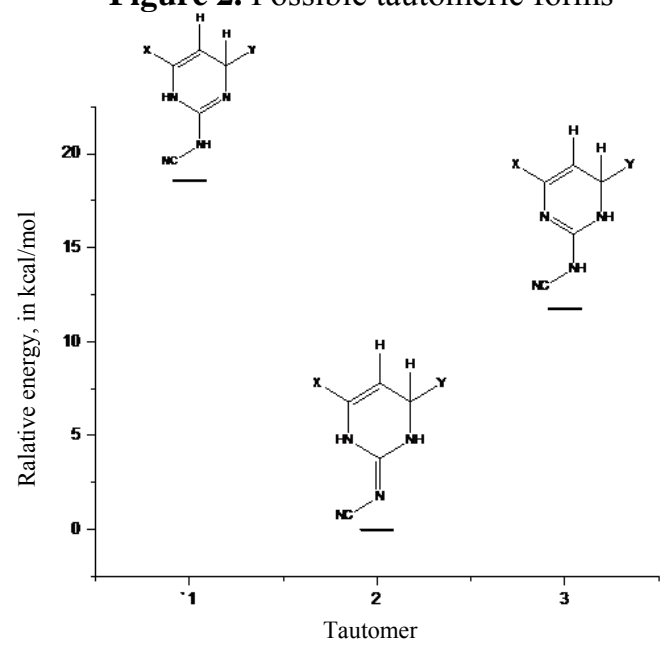

Figure 3. Relative energies of the tautomers 
The quantum mechanical calculations confirm, the cyanoiminopyrimidine exist as the more stable tautomer $\mathbf{D}$ and not the tautomers $\mathbf{B}$ or $\mathbf{C}$. The earlier ${ }^{10,14}$ reports also suggest the exist tautomeric form like $\mathbf{D}$ with other forms for cyanoiminopyrimidines.

Table 1. Calculated [DFT-B3LYP/6-31 g(d)] absolute energy (E in a.u), relative energy $(\Delta \mathrm{E}$ in $\mathrm{kcal} / \mathrm{mol}$ ) and dipole moment (in Debey) for tautomer $\mathbf{B}, \mathbf{C}$ and $\mathbf{D}$.

\begin{tabular}{cccc}
\hline Tautomer & $\mu$, Debey & E, a.u & $\Delta \mathrm{E}, \mathrm{kcal} / \mathrm{mol}$ \\
\hline $\mathrm{B}$ & 6.96 & -1028.8448958 & 18.57 \\
$\mathrm{C}$ & 2.12 & -1028.8557988 & 11.73 \\
$\mathrm{D}$ & 8.54 & -1028.8744871 & 0 \\
\hline
\end{tabular}

\section{Antimicrobial screening}

All the synthesized compounds were tested their antibacterial and antifungal activities. The results shows (Table 2) that all the tested compounds are active against both bacterias and fungi. Among the synthesized compounds, the compounds $\mathbf{4 e}$ and $\mathbf{4 g}$ are more active against gram positive (Bacillus subtilis and Staphylococcus aureus) as well as gram negative (Escherichia coli and Pseudomonas aeruginosa) bacterias and also comparable with the standard gentamicin. The compound $\mathbf{4 b}$ shows better activity against Escherichia coli when compared to other compounds.

The antifungal activities of these compounds show that most of the compounds are having very good antifungal activity and also greater than the standard fluconazole used for the test. Among the synthesized compounds, the compound $\mathbf{4 a}$ is more active against fungi and nearly two times more active against Aspergillus niger and Aspergillus flavus compared to standard.

Table 2. Assay of antimicrobial activity

\begin{tabular}{|c|c|c|c|c|c|c|c|c|c|c|}
\hline \multirow{2}{*}{$\begin{array}{l}\text { S. } \\
\text { No. }\end{array}$} & Microbes & \multicolumn{9}{|c|}{ Zone of inhibition, $\mathrm{mm}$ in diameter } \\
\hline & Bacteria & Control & Standard* & $4 a$ & 4b & 4c & 4d & $4 e$ & $4 f$ & $4 g$ \\
\hline 1 & Bacillus subtilis & - & 18 & 10 & 12 & - & 08 & 15 & 13 & 15 \\
\hline 2 & $\begin{array}{c}\text { Staphylococcus } \\
\text { aureus }\end{array}$ & - & 21 & 11 & 17 & 10 & 10 & 20 & 16 & 20 \\
\hline 3 & Escherichia coli & - & 20 & 13 & 19 & 12 & 12 & 18 & 16 & 16 \\
\hline 4 & $\begin{array}{c}\text { Pseudomonas } \\
\text { aeruginosa }\end{array}$ & - & 20 & 11 & 13 & 17 & 08 & 17 & 14 & 19 \\
\hline & Fungi & & & & & & & & & \\
\hline 5 & Aspergillus niger & - & 10 & 18 & 12 & 10 & 11 & 11 & 15 & 14 \\
\hline 6 & Aspergillus flavus & - & 11 & 16 & 12 & 11 & 15 & 08 & 10 & 10 \\
\hline
\end{tabular}

\section{Conclusion}

A new route for the synthesis of 2-cyanoimino-4-phenyl-6-(naphthalen-2-yl)-3,4-dihydro$1 H$-pyrimidine is proposed from the reaction of $\alpha, \beta$-unsaturated ketones with cyanoguanidine. The synthesized compounds are characterized by spectral studies and the more stable tautomeric form is identified by quantum mechanical calculation. The antimicrobial screening of synthesized compounds showed moderate to good activity against tested bacterias and fungi. 


\section{References}

1. Al-Abdulah E S, Al-Obaid A R, Al-Deeb O A, Habib E E and El-Emam A A, Eur J Med Chem., 2011, 46(9), 4642-4647; DOI:10.1016/j.ejmech.2011.08.003

2. Keri R S, Hosamani K M, Shingalapur R V and Hugar M H, Eur J Med Chem., 2010, 45(6), 2597-2605; DOI:10.1016/j.ejmech.2010.02.048

3. Amr A G E, Mohamed A M, Mohamed S F, Abdel-Hafez M A and Hammam Ael F G, Bioorg Med Chem., 2006, 14(16), 5481-5488; DOI:10.1016/j.bmc.2006.04.045

4. Schou C, Ottosen E R, Petersen H J, Bjorkling F, Latini S, Hjarnaa P V, Bramm E and Binderup L, Bioorg Med Chem Lett., 1997, 7(24), 3095-3100; DOI:10.1016/S0960-894X(97)10152-4

5. Kreutzberger A and Sellheim M, J Heterocyc Chem., 1985, 22(3), 721-723; DOI:10.1002/jhet.5570220321

6. Yagupolskii L M, Antepohl W, Artunc F, Handrock R, klebanov B M, Maletina I I, Marxen B, Petko K I, Quast U, Vogt A, Weiss C, Zibold J and Herzig S, J Med Chem., 1999, 42(25), 5266-5271; DOI:10.1021/jm990443h

7. Berthelot M, Helbert M, Laurence C, Le Questel L Y, Anvia F and Taft R W, J Chem Soc Perkin Trans., 1993, 2, 625-627; DOI:10.1039/P29930000625

8. Nekrasov D D, Chem Heterocycl Compd., 2005, 41(7), 809-819; DOI:10.1007/s10593-005-0231-3

9. Kosasayama A, Konno T, Higashi k and Ishikawa F, Chem Pharm Bull., 1979, 27(3), 841.

10. Hulme R, Zamora O D P, Mota E J, Pasten M A, Contreas-Rojas R, Miranda R, Valencia-Hernandez I, Correa-Basurto J, Trujillo-Ferrara J and Delgado F, Tetrahedron, 2008, 64(15), 3372-3380; DOI:10.1016/j.tet.2008.01.087

11. Aleksandrowicz P, Bukowska M, Maciejewski M and Prejzner J, Can J Chem., 1979, 57(19), 259-2598; http://dx.doi.org/10.1139/v79-419

12. Rong L, Wei X, Tao S, Lu Y, Xie R, Zhou J and Zong Z, Res Chem Intermed., 2012, 39(4), 1907-1916; DOI:10.1007/S11164-012-0724-5

13. EL-Rayyes N R, J Heterocycl Chem., 1982, 19(2), 415-419;

DOI:10.1002/jhet.5570190240

14. Moustafa A H, Shestakov A S and Shikhaliev K S, Chem Heterocycl Compd., 2012, 48(4), 613-619; DOI:10.1007/s10593-012-1034-y 